\title{
Teaching Listening Comprehension Skills: A Test-orientated Approach
}

\author{
Shao-Wen Su \\ Department of Applied English, National Chin-Yi University of Technology, Taiwan \\ Email: shaowen@ncut.edu.tw \\ Chung-Hsiang Liu \\ Language Center and Liberal Education Center, National Chin-Yi University of Technology, Taiwan \\ Email: simonliu@ncut.edu.tw
}

\begin{abstract}
Attributed to a "receptive skill" in the communicative process, listening comprehension would be the most arduous task of all four language skills. It is likely that EFL (English as a foreign language) students encounter various predicaments, of e.g. grasping main ideas of the dialogues in contexts, and in turn suffer from learning anxiety. The issue of how to assist the students in improving their listening competency is worth attention. This article is, therefore, intended for illustrating a test-orientated approach to teaching listening comprehension skills to EFL students through an analysis of sample questions about listening comprehension (i.e. Choosing the Right Picture, Short Questions, and Short Conversations) on GEPT tests at the elementary level and through provision of tips (i.e. Skim, Scan, Listen, Guess/Infer, Choose \& Write and Check) on how to answer the questions effectively. Implications for teaching listening comprehension are also made at the end of the paper.
\end{abstract}

Index Terms - General English Proficiency Test (GEPT), listening comprehension, receptive skill, teaching English as a foreign language (TEFL), test-orientated approach

\section{INTRODUCTION}

Among EFL countries, there has been a widespread belief that to elevate levels of English competency of their people is to boost up their competitive edge in the international arena in the $21^{\text {st }}$ century. The reason lies in that English is deemed linga franca widely used in every sector of communication, especially, international trade, politics, cultural exchange, science and technology (De Swaan, 1995; Salverda, 2002). Since the initiation of World Wide Web era in 1990, the role of English language has become even more crucial than ever before. There were over $75 \%$ English websites worldwide in 1999 alone (Press, 2000) while 95\% of the literature collected in SCI (Science Citation Index) was in print in English in 1997 (Garfield, 1998). In this light, the MOE in Taiwan enacts educational policies aiming at developing Taiwanese students in higher education system to become elites with a practical communication capability in English (Su, 2005; 2009a; 2009b). Not only is standardized English competency tests adopted to evaluate the students' English competency, but also the regulation of English graduation threshold is promulgated in myriads of higher education institutions ( $\mathrm{Su}, 2005 ; 2009 \mathrm{~b})$. Among the standardized English competency tests, e.g. GEPT (The General English Proficiency Test) ${ }^{1}$, TOEFL, TOEIC, IELTS (The International English Language Testing System), JET (Junior English Tests), TOEIC Bridge and Cambridge Main Suite, the GEPT has attracted the most attention. Since the GEPT development project of multiple test levels, i.e. the Elementary, Intermediate, High-intermediate, Advanced and Superior, reached completion in 2002, there have been four million examinees sitting for the tests. More than 300 junior high schools or high schools, hundreds of universities, private enterprises and government agencies in Taiwan recognize GEPT scores (Refer to Note 1). Taking the tests has become an enormous vogue in Taiwan.

Teaching listening comprehension is one of the major tasks in TEFL (teaching English as a foreign language) (Ur, 1989). Although listening is a "receptive skill", rather than a "productive skill", in the process of interpreting messages of what people utter (Lindsay \& Knight, 2006, p.47), listening comprehension would be the hardest of all the four language skills of i.e. listening, speaking, reading and writing, especially, to EFL learners. This situation can be traced to that listeners have to receive the message in a foreign language, de-code it and comprehend it instantly in a meaningful context; thereof, it would not be difficult to imagine that they might encounter a variety of hurdles, for example grasping main ideas of the dialogues in contexts, and therefore suffer from anxiety. Other conceivable

\footnotetext{
1 GEPT, a standardized test developed by The Language Training and Testing Center under the commission of the Ministry of Education in Taiwan, targets English learners at all levels in Taiwan. This test corresponds to Taiwan's English education framework, meets the specific needs of English learners in Taiwan for self-assessment, and provides institutions or schools with a reference for evaluating the English proficiency levels of their job applicants, employees, or students. The GEPT promotes a balanced English learning process, covering the four language skills of listening, reading, writing, and speaking with the goal of improving the general English proficiency level of Taiwanese learners (For more details, please refer to http://www.lttc.ntu.edu.tw/E_LTTC/E_GEPT.htm).
} 
predicaments are (1) hardship to link the words heard to the meanings in time, (2) failure to grasp the meanings of the sentences even when their understanding each word heard in the sentences, (3) mistaking one word for another that carries a similar pronunciation, (4) inability to remember the words, phrases or sentences just heard, (5) incapability to break a long conversation into meaningful units, and (6) failure to integrate every word heard into a meaningful chunk (Goh, 1997).

With those above-mentioned difficulties, one might not doubt that students/listeners have to go through several cognitive reactions (Wenden, 1991) in the listening process when encountering the listening problems. They would stop to search for the meaning of the words heard and try to translate them from L2 to L1. They might also stop to transform the words into pictures (Goh, 1997). Due to the pauses in the listening process, there is a likelihood that they miss, if not largely, part of the content in the conversation and lose tracks of the gist. Therefore, the issue as to how to help students sharpen listening comprehension skills are worthy of study.

This paper aims at exploring into how to teach effective listening comprehension skills by analyzing sample questions on GEPT tests at the elementary level based on three books (Lai, 2003; Liu, 2009; Zhang, 2003) related to General English Proficiency Test listening comprehension tests and by providing tips on how to answer them effectively. Implications for teaching listening comprehension are also made at the end of the paper.

\section{TIPS ON TAKING GEPT LISTENING COMPREHENSION TEST}

There are five steps suggested to do the GEPT listening comprehension test:

1. Skim (through the pictures and sentences)

2. Scan (for possible clues and underlie the key words)

3. Listen (to, especially, key words or sentences)

4. Guess/Infer (the possible answer from the context)

5. Choose and write (the correct answer)

6. Check (the unanswered questions)

First, test-takers skim through the pictures and/or sentences quickly while scanning for and underlie the key words. Second, they listen carefully to, especially, key words or sentences. Then, they have to choose and write the correct answer. If encountering some doubts and hesitation in choosing the right answers, they still have to answer by guessing the possible answer from the context and by linking questions asked to the key words heard. Once finished the tests, they need to check for the unanswered questions to make sure that no questions are left unanswered. These five to six steps particularly can be applied to answering questions on GEPT Listening Comprehension Test at the Elementary Level. The following is the brief introduction to three main parts on GEPT Listening Comprehension Test at the elementary level, followed by an analysis of common question types in Part I, Part II and Part III on GEPT Listening Comprehension Test at the Elementary Level along with tips on answering these different types of questions.

\section{AnAlysis of Three PARTs on GEPT Listening COMPREHENSION TEST AT THE ELEMENTARY LEVEL}

There are three parts on GEPT Listening Comprehension Test at the Elementary Level: "Choose the Right Picture", "Short Questions", and "Short Conversations".

\section{Part I: Choose the Right Picture}

There are 10 questions. Exam takers have to listen to each question along with three English sentences and then choose the matching picture. Exam takers are allowed to listen to each question one time only.

Part II: Short Questions

There are 10 questions all together for this part. Exam takers have to listen to each English sentence and then choose the right answer from three choices of answers. Exam takers are allowed to listen to each question one time only.

\section{Part III: Short Conversations}

There are 10 questions all together for this part. Exam takers have to listen to one conversation and a corresponding question before they choose a right answer from three choices of answers. Exam takers are allowed to listen to each conversation and question twice.

According to a synthetic analysis of the questions recurrent in the three books (Lai, 2003; Liu, 2009; Zhang, 2003), several related topics can be summarized, as shown in Table 1. 
TABLE 1:

COMMON QUESTION TYPES IN PART I ON GEPT LISTENING COMPREHENSION TEST AT THE ELEMENTARY LEVEL

\begin{tabular}{|c|c|}
\hline Related Topics & Example Questions \\
\hline Price/Amount/Frequency & $\begin{array}{l}\text { How much is it? } \\
\text { What costs } \$ 100 ? \\
\text { How many...? } \\
\text { How often...? }\end{array}$ \\
\hline Duration of Time & $\begin{array}{l}\text { How long does it take? } \\
\text { How long have you studied English? }\end{array}$ \\
\hline Activity + Day of the Week & $\begin{array}{l}\text { What does a person do on Sunday? } \\
\text { When does the man do? }\end{array}$ \\
\hline Actions & $\begin{array}{l}\text { What is the man doing? } \\
\text { What is the man going to do? } \\
\text { What has the man done? } \\
\text { What did the man do? } \\
\text { What can the man do? }\end{array}$ \\
\hline Job & $\begin{array}{l}\text { Who is the person? } \\
\text { What does the person do? }\end{array}$ \\
\hline Age & How old is the man? \\
\hline Weather & $\begin{array}{l}\text { How is the weather? } \\
\text { What is the weather like? } \\
\text { What season is it? }\end{array}$ \\
\hline Reason & Why is the man angry? \\
\hline Identify a person or thing & Which one...? \\
\hline Place & Where is the supermarket? \\
\hline Time & $\begin{array}{l}\text { What time is it? } \\
\text { What day is today? }\end{array}$ \\
\hline Feeling & How does the man feel? \\
\hline Way & How does the man do his job? \\
\hline
\end{tabular}

\section{A. Tips on Answering Questions in Part I: Choose the Right Picture}

When taking the exams, test takers have to keep alert to the recordings by making good use of senses of, especially, hearing and sight and coordinating them well. Rigy (1980) posits the important role of using senses in listening comprehension activities, echoing the correlation between senses used and memory capacity as indicated by Clark and Starr (1986). While learners are able to memorize $30 \%$ of what they try to learn through the sense of sight, the use of senses of both hearing and sight augments their memory capacity by 20\%, reaching at $50 \%$ (see Table 2).

TABLE 2:

THE RELATIONSHIP BETWEEN SENSES USED AND MEMORY CAPACITY

\begin{tabular}{|c|c|c|c|c|c|}
\hline Senses & memory & Senses & memory & Senses & memory \\
\hline \begin{tabular}{|l|} 
Read \\
Hear
\end{tabular} & $\begin{array}{l}10 \% \\
20 \%\end{array}$ & $\begin{array}{l}\text { See } \\
\text { Hear + See }\end{array}$ & $\begin{array}{l}30 \% \\
50 \%\end{array}$ & $\mid \begin{array}{l}\text { Speak } \\
\text { Speak + Do }\end{array}$ & $\begin{array}{c}70 \% \\
90 \%\end{array}$ \\
\hline
\end{tabular}

Four steps/tips are suggested for answering questions in Part I on GEPT Listening Comprehension Test at the Elementary Level effectively: "look at" the pictures for possible clues to the answers, "listening to" the clues carefully, "spot" the clues and "choose" the right answer by matching the question and clues found in the pictures provided on the listening comprehension test. Illustrations are provided herein to demonstrate how to apply these four tips, as follows.

Example Question (No.1) in Part I on GEPT Listening Comprehension Test at the Elementary Level (Zhang, 2003, p. 8)

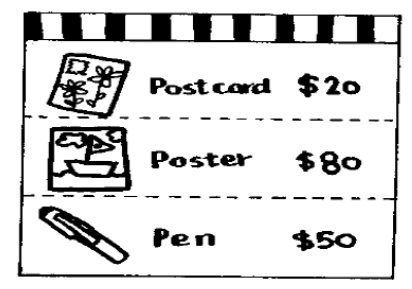

Question: What costs $\$ 80$ ?

A. The post card costs $\$ 80$.

B. The poster costs $\$ \mathbf{8 0}$. 
C. The pen costs $\$ 80$.

Analysis on Question (No.1) in Part I on GEPT Listening Comprehension Test at the Elementary Level

1. Eyes on the picture for possible clues:

Clues:

(1) what: postcard, poster, pen

(2) price: $\$ 20$ - twenty dollars

$\$ 80$ - eighty dollars

$\$ 50$ - fifty dollars

2. Hear: "What costs $\$ 80 "$

3. See: $\$ 80$ and poster

4. Choose: (B) by matching the question and the picture clue.

Example Question (No.2) in Part I on GEPT Listening Comprehension Test at the Elementary Level (Zhang, 2003, p. 57)

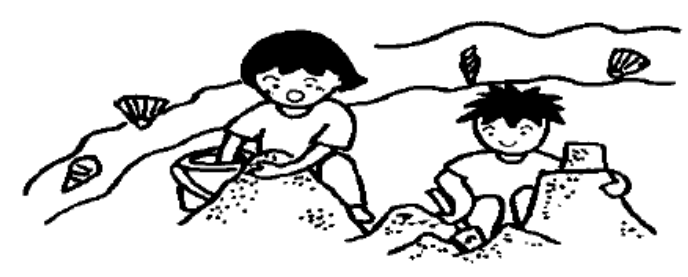

Analysis on Question (No. 2) in Part I

1. Eyes on the picture for clues:

Question: What are they doing?

A: There are two children playing on the beach.

B: They are playing on the beach.

C: They are very happy.

$\underline{\text { Two children }}+\underline{\text { play }}+\underline{\text { beach }}$

\section{Clues:}

(1) who: boy, girl, they

(2) where: beach

(3) what: play sand

2. Hear: "What/ doing?"

3. Choose: the answer (B) by matching the question and the right picture clue.

\section{B. Question Types in Part II: Short Question}

There are two question types in Part II:

1. Answering Short Questions

2. Responding to Statements

Examples of these two question types are given herein and an analysis of the example questions is provided as illustrations in the following sections.

a. Tips on Answering Short Questions in Part II on GEPT Listening Comprehension Test at the Elementary Level

There are common types of short questions that can be found in Part II on GEPT test at the elementary level, e.g. "W" questions, "H" questions, "Yes/No" questions and "Tag" questions, as illustrated in Table 3. The issue as to how to answer these questions depends on the clues containing in each question type. Table 3 indicates common short questions types that normally appear in Part II on GEPT Listening Comprehension Test at the Elementary Level and an analysis of the purposes of the questions. Recurrent questions or sentences are also listed in Table 3 for reference. 
TABLE 3:

COMMON SHORT QUESTION TYPES IN PART II ON GEPT LISTENING COMPREHENSION TEST AT THE ELEMENTARY LEVEL

\begin{tabular}{|c|c|c|}
\hline Question Types & Purposes of the Questions & Example Questions/Sentences \\
\hline $6 " W "$ Questions & $\begin{array}{l}\text { The purposes of } 6 \text { "W" questions are to ask specific information, } \\
\text { starting out the questions with a question adverb, for example } \\
\text { "what", "who", "where", "when", "why", or "whose"...? }\end{array}$ & $\begin{array}{l}\text { "What is your occupation?" } \\
\text { "Who is the boy wearing a hat?" } \\
\text { "Where did you do last night?" } \\
\text { "When are you going to the movie?" } \\
\text { "Whose car is it?" }\end{array}$ \\
\hline "H” Question & $\begin{array}{l}\text { The purpose is to find out opinions and feelings of other people. } \\
\text { "How....?" }\end{array}$ & "How do you like your trip to Japan?" \\
\hline Yes/No Question & The purpose is to invite or ask for opinions or ideas. & $\begin{array}{l}\text { "Would you like to...?" } \\
\text { "May I ...?" } \\
\text { ”Do you think...?" } \\
\text { "Do you know...?" }\end{array}$ \\
\hline Tag Question & $\begin{array}{l}\text { The purposes of tag questions are (1) to state opinions and (2) to } \\
\text { seek the agreement of other people. }\end{array}$ & $\begin{array}{l}\text { "This pizza's delicious, isn't it? } \\
\text { "You like the new teacher, don't you?" }\end{array}$ \\
\hline
\end{tabular}

b. Different Types of Statements in Part II

There are several types of statements that can be found in part two on GEPT test at the elementary level, as indicated in Table 4.

TABLE 4:

TyPES OF STATEMENT COMMONLY FOUND In PART TwO ON GEPT TEST AT THE ELEMENTARY LEVEL

\begin{tabular}{|c|c|}
\hline Statement Types & Example Dialogues \\
\hline $\begin{array}{l}\text { State a problem: } \\
\text { This kind of questions is purported to express one's regret and } \\
\text { pity. }\end{array}$ & $\begin{array}{l}\text { A: I have a terrible headache. } \\
\text { B: I am sorry to hear that./That's too bad. }\end{array}$ \\
\hline State your suggestions or proposition & $\begin{array}{l}\text { 1. A: I think you need a larger size. } \\
\text { B: You're right. I've gotten a little fat lately. } \\
\text { 2. A: I think you should put on a jacket. } \\
\text { B: Come on. It's } 23 \text { degree outside. } \\
\text { 3. A: Let's order pizza. } \\
\text { B: Come on. You know I don't like pizza. }\end{array}$ \\
\hline State your wish & $\begin{array}{l}\text { A: I hope I didn't call when you were busy. } \\
\text { B: Don't worry. I was just watching TV. }\end{array}$ \\
\hline State your situation & $\begin{array}{l}\text { A: I really can't play tennis very well, but I can play } \\
\text { badminton. } \\
\text { B: I know what you mean; tennis is very difficult. }\end{array}$ \\
\hline State your opinion & $\begin{array}{l}\text { A: I think your brother looks just like you. } \\
\text { B: Well, I'm a little fatter than he is. }\end{array}$ \\
\hline $\begin{array}{l}\text { State your compliments: } \\
\text { Answer with your appreciation such as "Thank you". }\end{array}$ & $\begin{array}{l}\text { A: That's a beautiful dress! } \\
\text { B: Thanks. I got it on sale. }\end{array}$ \\
\hline Greeting/Introducing & $\begin{array}{l}\text { A: Let me introduce to my sister. } \\
\text { B: Nice to meet you. My name is Mary. }\end{array}$ \\
\hline Gossiping & $\begin{array}{l}\text { 1. A: I saw your English teacher in the store this morning. } \\
\text { B: I hope she didn't tell you about my last test. } \\
\text { 2. A: I heard you were going to study in Canada this coming } \\
\text { summer. } \\
\text { B: No, actually I want to go to the United States. }\end{array}$ \\
\hline State your comparison & $\begin{array}{l}\text { A: Those sweaters are a lot cheaper than these. } \\
\text { B: Yeah, but these are a lot nicer. }\end{array}$ \\
\hline
\end{tabular}

c. Tips on Answering Questions on Part II: Short Questions

Three gimmicks on how to answer short questions, i.e. to skim, scan, listen and choose, are indicated as follows.

1. Skim through all three answers quickly.

2. Scan to look for clues (e.g. key words, patterns, repeated words).

3. Listen to the question carefully and pay attention to the clues in the question.

4. Choose an answer according to the clues.

Three example questions from Zhang (2003) are used as examples to demonstrate how to answer the questions effectively based on the four gimmicks.

Example Question (No.1) in Part II (Zhang, 2003, p. 4)

Choose the best answer to the question.

A. Well, after I eat breakfast, I do my homework.

B. I ate breakfast and then did my homework.

C. Sunday will be February 1. 


\section{Analysis on Question (No.1) in Part II}

1. Skim through all the three answers quickly.

2. Scan for possible clues.

Clues:

(1) Repeated words: "eat breakfast"

(2) Different words: "do homework"

"did homework"

"will be...."

3. Hear: "What do you do...?"

(1) Activity--homework

(2) Use auxiliary verb "do"

4. Choose: "(A) Well, after I eat breakfast, I do my homework."

Example Question (No.2) in Part II (Zhang, 2003, p. 10)

Choose the best answer to the question.

A. No, he didn't.

B. No, he hasn't.

C. No, he isn't.

\section{Analysis on Question (No.2) in Part II}

1. Skim through all the three answers quickly.

2. Scan for possible clues.

Clues:

(1) Repeated words: "No, he"

(2) Different words: "didn't", "hasn't", "isn't"

3. Hear: "Has your brother decided what he's going to do next year?"

Take note of the clue: "Has"

4. Choose: “(B) No, he hasn't."

Example Question (No.3) in Part II (Zhang, 2003, p. 10)

Choose the best response to the statement.

A. Nice to meet you. My name is Sarah.

B. No, I don't have a sister.

C. I have two sisters, actually.

Analysis on Question (No.3) in Part II

1. Skim through all the three answers quickly.

2. Scan for possible clues.

\section{Clues:}

(1) repeated words: "have", "sister".

(2) different words: (A) introduce oneself.

(B) and (C) talk about "sister".

3. Hear: "Let me introduce..."

This question belongs to greeting/ introducing statement.

Introduce one person to another.

4. Choose: "(A) Nice to meet you. My name is Sarah."

C. Tips on Answering Questions on Part III: Short Conversation

Tips:

1. Skim all the answers provided quickly.

2. Scan to see if there is any pattern based on key word/words.

3. Guess/infer the question from the answers.

4. Listen to the question carefully.

5. Focus on the key sentences with the key word/words in them.

6. Find and choose the right answers according to the questions.

Example Question (No.1) in Part III (Zhang, 2003, p. 11)

Choose the best answer to the question according to the conversation.

A. She stayed inside today.

B. She has been outside today.

C. She likes cold weather.

\section{Analysis on Question (No.1) in Part III}

1. Skim all the answers provided.

2. Scan the answer options to see if there is any particular sentence pattern or key word/words.

Answer options:

A) stayed inside 
B) has been outside

C) likes cold weather

3. Guess/Infer the question from the answers.

4. Hear the question: "Which statement is true about the woman?"

5. Focus on the key sentence: "You've been inside all morning."

6 . Find and choose "(B) She has been outside today."

\section{CONCLUSION AND IMPLICATIONS}

In an EFL listening comprehension classroom, it is imperative that teachers provide their students with authentic materials (Breen, 1985; Lindsay \& Knight, 2006; Taylor, 1994) as much as possible. Teaching materials adopted should be related to learners' background knowledge, interest and curiosity as evidences (MacDonald, Bager, \& White, 2000) show a positive correlation between learner authenticity and students' learning achievement. Authentic social situations based on the content of listening materials used in the classroom should be re-emerged where students can transform simulated communication into authentic communication and further apply the simulated practice into real world communication. According to MacDonald et al. (2000), the more the listening material is related to students' experience and background knowledge and allows the students to interact with it, the better they understand and learn.

Designing step by step listening activities through pre-listening, listening and post-listening tasks (refer to Lindsay \& Knight, 2006) help learners meet classroom authenticity, reach learner authenticity, and motivate them to communicate with the texts and other learners in the classroom. In doing so, learning and teaching goals and purposes can be reached and, in turn, students' listening comprehension proficiency can be enhanced. In addition, as a saying goes, "Practice makes perfect", students' devoting themselves to practicing doing listening comprehension tests as much as possible pays off.

Equally crucial for learners is to acknowledge their own listening difficulties or weaknesses and learn from the mistakes. It is, more often than not, lexical and syntactic problems are detrimental to their listening comprehension (Wenden, 199), for example learners' limited vocabulary and lack of understanding of discourse genres contributing to listening difficulties (Goh, 1997). Learners' inefficient memory and unfamiliarity with intonation, stress, special accents, idioms and slang of a foreign language (Wenden, 1991) also act as hampers to their listening comprehension. Speedy speeches add to the gravity of the listening comprehension impediments. Personal traits, for instance sluggishness, timidity and reserve, as opposed to activity, liveliness and vivacity, harmfully impact students' achievement in listening comprehension (Wenden, 1991). Physical hindrances also pose as negative effects. Listeners in an emotional status, for example stress, nervousness or anxiety, are inclined to be disadvantageous in listening comprehension; likewise, people who suffer from physical problems like fatigue or illness are likely to be in a similarly negative situation.

On the part of teachers, providing students with gimmicks (i.e. Skim, Scan, Listen, Guess/Infer, Choose \& Write and Check) on how to answer questions effectively enhances students' achievement in taking listening comprehension tests. More importantly, students have to engage themselves in an active, rather than passive, persistent, rather than impatient, and long-term commitment to learning English as a foreign language as "Rome is not built in one day".

\section{ACKNOWLEDGEMENT}

The author of this paper would like to extend gratitude to National Science Council in Taiwan for its research grants (NSC99-2410-H-167-002).

\section{REFERENCES}

[1] Breen, M. P. (1985). Authenticity in the language classroom. Applied Linguistics, 6(1), 60-70.

[2] Clark, L. \& Starr, I. (1986). Secondary and Middle School Teaching Methods. New York: MacMillan.

[3] De Swaan, A. (1995). The language constellation of the European Union. A perspective from the political sociology of language. Paper for the Second European Sociological Association Conference, Budapest, 30 August-2 September.

[4] Garfield, E. (1998). Mapping the world of science. Paper presented at the 150 Anniversary Meeting of the American Association for the Advancement of Science, Philadelphia, PA, 14 February.

[5] Goh, C. (1997). Metacognitive awareness and second language listeners. ELT Journal, 51(4), 361-69.

[6] Lai, S.-X. (2003). GEPT Listening Comprehension Test (Chinese). Taipei, Taiwan: Ivy League Jolihi.

[7] Liu H.-R. (2009). Tung Hua New Century Series: Basic Modules of GEPT Tests (Chinese). Taipei, Taiwan: Tung Hua Company.

[8] Lindsay, C., \& Knight, P. (2006). Learning and Teaching English: A Course for Teachers. New York: Oxford University Press.

[9] MacDonald, M., Bager, R., \& White, G. (2000). The real thing?: Authenticity and academic listening. English for Specific Purposes, 19, 253-267.

[10] Press, L. (2000). The state of the Internet: Growth and gaps. The State of the Internet: Global Perspectives. The Internet Society. Retrieved June 6, 2011, from http://www.isoc.org/inet2000/cdproceedings/8e/8e_4.htm

[11] Rigy, R. P. (1980). Audio-visual Aids and Techniques in Managerial and Supervisory Learning. London: Hamial Hamiton.

[12] Salverda, R. (2002). Language diversity and international communication: Some reflections why English is necessary but not enough. English Today, 18(3). 3-11.

[13] Su, S.-W. (2005). Graduation threshold of English competency: A needs analysis from the perspective of technological institute 
students (Chinese). Educational Review, 24, 47-66.

[14] Su, S.-W. (2009a). A reflection on the teaching of foreign language teachers (Chinese). Journal of Cheng-Shiu University, 22, 357-372.

[15] Su, S.-W. (2009b). A study of graduation threshold of English competency from the perspective of EFL teachers of technological institutions in Southern Taiwan (Chinese). Journal of National Kaohsiung Normal University, 27, 37-60.

[16] Taylor, D. (1994). Inauthentic authenticity or authentic inauthenticity? TESL-EJ, 1(2). Retrieved November 1, 2006 from http://www-writing.berkeley.edu/TESL-EJ/ej02/a.1.html

[17] Ur, P. (1989). Teaching Listening Comprehension. Cambridge: Cambridge University Press.

[18] Wenden, A. (1991). Learner Strategies for Learner Autonomy. Hemel Hempstead, UK: Prentice Hall.

[19] Zhang, Y.-C. (2003). GEPT: Elementary-level Learning Comprehension Module (Chinese). Taipei, Taiwan: Crane Publishing Co.

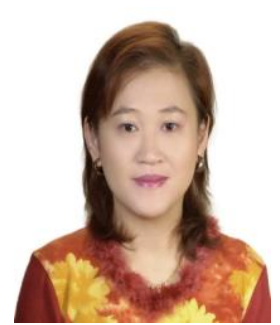

Shao-Wen Su was born in Tainan, Taiwan. She received her Doctor of Philosophy $(\mathrm{PhD})$ degree in Education from the University of Newcastle, Australia in 2003, an MA in English Literature and Language, Taiwan in 1990 and a BA in Foreign Literature and Languages, Taiwan in 1987.

She teaches as an associate professor at the Department of Applied English, National Chin-Yi University of Technology, Taiwan. She has been teaching EFL in colleges and universities for nearly 19 years.

Her research interests mainly include areas of English writing, English literature and ESP instructions as well as curriculum design and evaluation. Currently, she has embarked on exploring issues of difficulties that teaching faculty in fields of humanities and social sciences encounter and ways to elevate their research capability. Her further study will focus on possible correlations between teaching efficiency and academic performance and between research belief/motivation and academic performance.

Her recent publications include: (1) $\mathrm{Su}$, Shao-Wen (2011/August). A content-based English listening and speaking class for hospitality purposes. Theory and Practice in Language Studies, 8 (forthcoming). (2) Chen, Yuan-Shan \& Su, Shao-Wen (2012/April). A genre-based approach to teaching EFL summary writing. ELT Journal, 66(2) (forthcoming). (3) Su, Shao-Wen (2010). English placement practice and instruction: A needs analysis from the perspective of technological university students. Journal of National Kaohsiung Normal University, 29. (4) Su, Shao-Wen (2010). Motivating and justifiable: Teaching Western literature to EFL students at a Taiwanese university of science and technology. TESL-EJ, 14(1). (5) Su, Shao-Wen (2009). A study of graduation threshold of English competency from the perspective of EFL teachers of technological institutions in Southern Taiwan. Journal of National Kaohsiung Normal University, 27. (6) Su, Shao-Wen (2009). Perceptions on elevating academic research capability: A study from the perspective of humanities and social science teachers in a private technological university. Chung Cheng Educational Studies, 8(2). (7) Su, Shao-Wen (2009). A reflection on the teaching of foreign language teachers. Journal of Cheng Shiu University, 22. (8) $\mathrm{Su}$, Shaowen (2009). Arthur Miller's Death of a Salesman as a modern tragedy of a father. Studies in English Language and

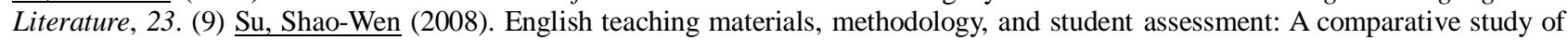
the perceptions of junior college students and teachers. English Teaching and Learning, 32(1). (10) Su, Shaowen (2007). Absurdity and certitude: Waiting for Godot as the Theatre of the Absurd. Studies in English Language and Literature, 20. (11) Su, Shao-Wen (2007). Tea or coffee: A study of the beverage choice pattern and its affecting factors at teatime in Kaohsiung, Taiwan. Asia Pacific Management Review, 12(4). (12) Su, Shaowen (2006). Beyond the unconscious: "Gaze” in Peter Shaffer's Equus. Tamkang Review, 36(3). (13) Su, Shao-Wen (2005). Graduation threshold of English competency: A needs analysis from the perspective of technological institute students. Educational Review, 24.

Dr. Su is a member of ETRA (The English Teaching and Research Association) and ETA (English Teachers' Association) in Taiwan. She is also one of the editors of Journal of Language Teaching and Research.

Chung-Hsiang Liu was born in Taichung, Taiwan in 1956. He got his MA in TESOL from Central Missouri State University, Missouri, USA in 1987 and BA in English from National Taiwan Normal University, Taiwan in 1978. He teaches as a lecturer at the Language Center and Liberal Education Center, National Chin-Yi University of Technology, Taiwan. He has been teaching EFL in high school and university for more than 20 years.

His research interests are mainly in the areas of transnational marriages in Taiwan and curriculum design and evaluation. Lately, he is focusing on issues of how to apply AHP (Analytic Hierarchy Process) to the evaluation of students' English proficiency.

His recent publications include: (1) Yu, Teng-Huang \& Liu, Chung-Hsiang (2011/Janaury). Transnational marriage in Taiwan: multi-purpose Vietnamese ethnic stores and eateries. Studies in Comparative Culture, Japan. (2) Yu, Teng-Huang \& Liu, Chung-Hsiang (2010). Transnational marriages in Japan and Taiwan: Issues and challenges. Journal of the College of Humanity \& Society, National Chin-yi University of Technology. (3) Liu, Chung-Hsiang (2010). Curriculum elements in enhancing the effectiveness of the assessment of English proficiency of students: A university of technology in Taiwan. The $8^{\text {th }}$ Academic Seminar of Management in Chin-yi University of Technology. (4) Liu, Chung-Hsiang (2010/June). Songs to enhance active learning in Taiwanese college EFL classes. 2010 Taiwan TESOL Conference. 